\title{
Splenic Atrophy in Experimental Stroke Is Accompanied by Increased Regulatory T Cells and Circulating Macrophages ${ }^{1}$
}

\author{
Halina Offner ${ }^{*}, \dagger, \ddagger, 2$, Sandhya Subramanian ${ }^{*}$, Susan M. Parker ${ }^{\ddagger}$, Chunhe Wang ${ }^{*}, \dagger$, Michael E. \\ Afentoulis ${ }^{\star}$, Anne Lewis $\S$, Arthur A. Vandenbark ${ }^{\star}, \dagger, \uparrow$, and Patricia D. Hurn $\ddagger$ \\ * Neuroimmunology Research, Veterans Affairs Medical Center, Portland, OR 97239 \\ $\dagger$ Department of Neurology, Oregon Health \& Science University, Portland, OR 97239 \\ $\$$ Department of Anesthesiology and Perioperative Medicine, Oregon Health \& Science University, Portland, \\ OR 97239
}

$\S$ Oregon National Primate Research Center, Oregon Health \& Science University, Beaverton, OR 97006

II Department of Molecular Microbiology and Immunology, Oregon Health \& Science University, Portland, OR 97239

\section{Abstract}

Induction of stroke not only produces local ischemia and brain damage, but also has profound effects on peripheral immune responses. In the current study, we evaluated effects on spleen and blood cells 4 days after stroke induction. Surprisingly, there was a less inflammatory cytokine profile in the middle cerebral artery occlusion-affected right brain hemisphere at $96 \mathrm{~h}$ compared with earlier time points. Moreover, our results demonstrate that stroke leads to splenic atrophy characterized by a reduction in organ size, a drastic loss of splenocyte numbers, and induction of annexin $\mathrm{V}^{+}$and $\mathrm{TUNEL}^{+}$cells within the spleen that are in the late stages of apoptosis. The consequence of this process was to reduce $\mathrm{T}$ cell proliferation responses and secretion of inflammatory cytokines, resulting in a state of profound immunosuppression. These changes produced a drastic reduction in $\mathrm{B}$ cell numbers in spleen and blood, and a novel increase in $\mathrm{CD}^{+} \mathrm{FoxP}^{+}$regulatory $\mathrm{T}$ cells. Moreover, we detected a striking increase in the percentage of nonapoptotic CD11 $\mathrm{b}^{+}$VLA-4-negative macrophages/monocytes in blood. Immunosuppression in response to brain injury may account for the reduction of inflammatory factors in the stroke-affected brain, but also potentially could curtail protective immune responses in the periphery. These findings provide new evidence to support the contention that damage to the brain caused by cerebral ischemia provides a powerful negative signal to the peripheral immune system that ultimately induces a drastic state of immunosuppression caused by cell death as well as an increased presence of $\mathrm{CD}^{+} \mathrm{FoxP}^{+}$regulatory $\mathrm{T}$ cells.

Induction of inflammatory factors clearly contributes to postocclusion damage in strokeinjured brain tissue $(1,2)$. Damage sustained by the brain during stroke also results in rapid systemic changes in inflammatory cells, cytokines, and chemokines in the circulation and peripheral immune organs. In patients with stroke, C-reactive protein, white blood cell counts, and plasma IL-6 levels were increased on admission and persisted for $>7$ days (3). A later study

\footnotetext{
${ }^{1}$ This work was supported by U.S. Public Health Service National Institutes of Health Grants NS33668, NR03521, NS49210, RR00163, and the Biomedical Laboratory R\&D Service, Department of Veterans Affairs.

2 Address correspondence and reprint requests to Dr. Halina Offner, Neuroimmunology Research R\&D-31, Portland Veterans Affairs Medical Center, 3710 SW U.S. Veterans Hospital Road, Portland, OR 97239. E-mail address: offnerva@ohsu.edu.

Disclosures

The authors have no financial conflict of interest.
} 
from this group found a significant correlation in peak plasma IL-6 levels measured within the first week after the stroke with brain infarct volume, stoke severity, and long-term clinical outcome (4). Additionally, experimental stroke in mice caused a reduction in immune cells in peripheral lymphoid organs and decreased secretion of TNF- $\alpha$ and IFN- $\gamma$ that contributed to spontaneous bacterial infections, a leading cause of mortality in stroke patients (5). Moreover, occlusion of the left or right hemispheres in rats caused a transient reduction in total splenocytes and $\mathrm{CD}^{+} \mathrm{T}$ cells, and increased splenocyte proliferation to mitogens (6).

In a recent report (7), we confirmed elevated plasma IL-6 levels in middle cerebral artery occlusion (MCAO) ${ }^{3}$ mice through $22 \mathrm{~h}$ after occlusion, as well as increased IFN- $\gamma$ and MCP-1 at the $6 \mathrm{~h}$ time point. Moreover, we observed striking and consistent changes in the spleen. At both the 6- and 22-h time points, activated spleen cells from stroke-injured mice secreted significantly enhanced levels of the inflammatory factors TNF- $\alpha$, IFN- $\gamma$, IL-6, MCP- 1 , and IL-2, with increased secretion of the anti-inflammatory factor, IL-10, only at the 22-h time point. Moreover, unstimulated spleen tissue from stroke mice had increased expression of message for MIP-2, CCR2, CCR7, and CCR8 at the 6-h time point, and MIP-2, IP-10, CCR1, and CCR2 at the 22-h time point. Similar increases in secretion of TNF- $\alpha$, IL-6, IL-2, and IFN$\gamma$ (lymph node only) were observed only at the 22-h time point in activated lymph node and blood mononuclear cells. Interestingly, IL-1 $\beta$ was not detected at either time point in any of the peripheral lymphoid organs or in plasma, suggesting that the source of this cytokine was solely from injured brain. These data demonstrate that focal cerebral ischemia produced distal effects in lymphoid organs.

However, this early activation of systemic immunity is likely transient. Immunodeficiency following stroke has been widely observed and appears to contribute significantly to widespread infections that are often lethal. A previous report (8) demonstrated a reduction in the number of immune cells and a significant increase in the percent of TUNEL ${ }^{+} \mathrm{B}$ cells, $\mathrm{T}$ cells, and NK cells in blood, spleen, and thymus in mice after stroke. The reduced cell number accounted for decreased production of IFN- $\gamma$, resulting in increased mortality caused by bacteremia and pneumonia.

The underlying process that results in widespread immunosuppression and concurrent systemic infections after stroke induction (5) is not well-understood. However, it has been proposed that stroke-induced immune depression results from an overactivation of the sympathetic nervous system $(9,10)$, leading to rapid, severe, and sustained lymphopenia and altered lymphocyte and monocyte function. In the current report, we evaluated the effects of MCAO vs sham treatment on spleen cell morphology and function during the period just after the immunostimulatory phase $(22 \mathrm{~h})$ and continuing through 4 days after stroke induction. We found a dramatic reduction in spleen cellularity and response to mitogens, due in part to an overabundance of Fox $3^{+}$regulatory $\mathrm{T}$ (Treg) cells that are known to inhibit protective immune cells, including $\mathrm{CD}^{+}$and $\mathrm{CD} 8^{+} \mathrm{T}$ cells, B cells, NK cells (11-14), and circulating CD11b ${ }^{+}$monocytes.

\section{Materials and Methods}

\section{Animals}

The study was conducted in accordance with National Institutes of Health guidelines for the use of experimental animals, and the protocols were approved by the Institutional Animal Care and Use Committee. Age-matched, sexually mature male mice (C57BL/6J; Charles River Laboratories; body weight $20-25 \mathrm{~g}$ ) were used in all experiments.

\footnotetext{
${ }^{3}$ Abbreviations used in this paper: MCAO, middle cerebral artery occlusion; Treg, regulatory T; CBA, cytometric bead array; IP-10, IFN-inducible protein-10; DC, dendritic cell; PI, propidium iodide.
} 


\section{Ischemic model}

Focal cerebral ischemia was induced by $90 \mathrm{~min}$ of reversible MCAO under halothane anesthesia, as described previously $(15,16)$. In brief, mice were anesthetized with $1.5-2.0 \%$ halothane in $\mathrm{O}_{2}$-enriched air. The common carotid artery was exposed and the external carotid artery was ligated and cauterized. Unilateral MCAO occlusion was performed by inserting a 6-0 nylon monofilament surgical suture with heat-blunted tip into the internal carotid artery via the external carotid artery stump. The tip was positioned at a distance of $6 \mathrm{~mm}$ beyond the internal carotid/pterygopalatine artery bifurcation, and occlusion was confirmed by a LaserDoppler flow (Moor Instruments) probe positioned over the ipsilateral hemisphere at the mid ear-to-eye distance. The suture was then secured in place, and the animal was awakened and assessed for intraischemic neurological deficit, i.e., presence or absence of forelimb weakness, torso turning to the ipsilateral side when held by tail, circling to affected side, inability to bear weight on affected side, or spontaneous locomotor activity or barrel rolling. Any animal without a visible deficit was excluded from the study. At end-ischemia (90 min), the animal was briefly reanesthetized and reperfusion was initiated by filament withdrawal. Shamoperated mice were treated identically with the exception of insertion of the filament to produce occlusion.

\section{Physiological measurements}

Intraoperative rectal temperature was controlled in all animals, $\left(36.9\right.$ and $36.7^{\circ} \mathrm{C}$ in MCAO and shams, respectively). Occlusion was confirmed in all MCAO animals.

\section{Isolation of mononuclear cells from spleen and thymus}

Spleens and thymi were isolated from sham and MCAO mice and a single-cell suspension was prepared by passing the tissue through a $100-\mu$ m nylon mesh screen. The cells were washed using RPMI 1640 and the red cells lysed using red cell lysis buffer $\left(8.3 \mathrm{~g} \mathrm{NH}_{4} \mathrm{Cl}\right.$ in $0.01 \mathrm{M}$ Tris- $\mathrm{HCl}(\mathrm{pH} 7.4))$ and incubated for $8 \mathrm{~min}$. The cells were then washed twice with RPMI 1640, counted, and resuspended in stimulation medium containing 10\% FBS for phenotyping, cell culture, and cytokine detection by cytometric bead array (CBA) and ELISA.

\section{Terminal histopathology}

The brains were harvested after $96 \mathrm{~h}$ of reperfusion and sliced into five 2-mm thick coronal sections for staining with $1.2 \%$ triphenyltetrazolium chloride (Sigma-Aldrich) in saline as described previously (15). Infarction volume was measured using digital imaging (MTI Series 68 video camera) and image analysis software (Sigma Scan Pro; Jandel). The area of infarct was measured on the rostral and caudal surfaces of each slice and numerically integrated across the thickness of the slice to obtain an estimate of infarct volume in each slice. Spleens were harvested and fixed in 10\% formalin. Histologic sections were stained with H\&E and examined by light microcopy.

\section{Cytokine determination by CBA}

Spleen and blood mononuclear cells were cultured in a 24-well flat-bottom culture plate with 0.5 or $0.75 \mu \mathrm{g} / \mathrm{ml}$ Con A or $5 \mu \mathrm{g} / \mathrm{ml}$ plate-bound anti-CD3 and $2 \mathrm{mg} / \mathrm{ml}$ anti-CD28 Abs at $4 \times$ $10^{6}$ cells/well in stimulation medium containing $10 \%$ FBS for $24 \mathrm{~h}$. Supernatants were then harvested and stored at $-80^{\circ} \mathrm{C}$ until tested for cytokines. The mouse inflammation CBA kit was used to detect IL-12p40, TNF- $\alpha$, IFN- $\gamma$, MCP-1, IL-10, and IL-6 simultaneously (BD Bioscience). Briefly, $50 \mu \mathrm{l}$ of sample was mixed with $50 \mu \mathrm{l}$ of the mixed capture beads and 50 $\mu \mathrm{l}$ of the mouse PE detection reagent. The tubes were incubated at room temperature for $2 \mathrm{~h}$ in the dark, followed by a wash step. The samples were then resuspended in $300 \mu \mathrm{l}$ of wash buffer before acquisition on the FACScan. The data were analyzed using CBA software (BD Biosciences). Standard curves were generated for each cytokine using the mixed bead standard 
provided in the kit and the concentration of cytokine in the supernatant was determined by interpolation from the appropriate standard curve.

\section{Proliferation assay}

Splenocytes and blood mononuclear cells from mice were prepared (17). A total of $4 \times 10^{5}$ cells/well were plated on standard 96-well flat-bottom tissue-culture plates for $72 \mathrm{~h}$ at $37^{\circ} \mathrm{C}$ and $7 \% \mathrm{CO}_{2}$ with and without mitogens and in the presence of $0.5 \mu \mathrm{Ci}$ of $\left[{ }^{3} \mathrm{H}\right]$ thymidine during the last $18 \mathrm{~h}$. Cells were harvested onto glass fiber filters, and thymidine uptake was determined by liquid scintillation.

\section{Analysis of cell populations by FACS}

Four-color (FITC, PE, PerCP, allophycocyanin) fluorescence flow cytometry analyses were performed to determine the phenotypes of splenocytes and blood mononuclear cells. Spleens were harvested, and single-cell suspensions were obtained by mechanical disruption. Cells were washed with staining medium (PBS containing $0.1 \% \mathrm{NaN}_{3}$ and $2 \% \mathrm{FCS}$ ) and stained with a combination of the following mAbs: CD3 (145-2C11), CD4 (GK1.5), CD8 (53-6.7), CD11b (M1/70), CD11c (HL-3), CD19 (1D3), CD25 (PC61), LFA-1 (I21/7), VLA-4 (PS/2), FoxP3, and annexin $\mathrm{V}$ for $20 \mathrm{~min}$, on ice. After incubation with $\mathrm{mAb}$, cells were analyzed with a FAC-SCalibur (BD Biosciences). Forward and side scatter parameters were chosen to identify lymphocytes. Data were analyzed using CellQuest software (BD Biosciences). For each experiment, cells were stained with appropriate isotype control Abs to establish background staining and to set quadrants before calculating the percentage of positive cells.

\section{RNA isolation and RT-PCR}

Total RNA was isolated from splenocytes and brain cells using the RNA-easy mini kit protocol (Qiagen) and then converted to cDNA using oligo dT, random hexamers, and Superscript RT II enzyme (Invitrogen Life Technologies). Real-time PCR was performed using Quantitect SYBR Green PCR master mix (Qiagen) and primers (synthesized by Applied Biosystems). Reactions were conducted on the ABI Prism 7000 Sequence Detection System (Applied Biosystems) to detect the housekeeping gene L32, IFN- $\gamma$, TNF- $\alpha$, IL-10, IL-4, IL-6, TGF- $\beta 1$, IL-13, FoxP3, IL-1 $\beta$, RANTES, MIP-2, IFN-inducible protein-10 (IP-10), CCR1, CCR2, CCR3, CCR5, CCR6, CCR7, and CCR8.

\section{TUNEL}

DNA damage was determined as a means of assessing cell viability using a TUNEL assay, In Situ Cell Death Detection Fluorescein kit (Roche Applied Science). The kit reagents detect damaged cells in situ by specific end labeling and detection of DNA fragments produced by the apoptotic process. To perform TUNEL assay in splenocytes, PBS-suspended cells were prestained (optional) with cell surface markers and then fixed in $2 \%$ paraformaldehyde at room temperature for $60 \mathrm{~min}$ with agitation. To perform the TUNEL assay in paraffin-embedded tissue sections, the sections were first deparaffinized with a standard histological protocol. Splenocytes or sections were permeabilized with Triton $\mathrm{X}-100$ at $4^{\circ} \mathrm{C}$ for $2 \mathrm{~min}$, then flooded with TdT enzyme and digoxigenin-dUTP reaction buffer (TUNEL) reagent for $60 \mathrm{~min}$ at $37^{\circ}$ $\mathrm{C}$, followed by direct analysis with flow cytometer (for splenocytes) or fluorescence microscope (tissue sections) to determine the percentage of apoptotic cells. Negative controls were performed by substituting PBS for TdT enzyme in the preparation of working solutions. Positive controls were prepared by treating cells or sections with DNase I for $10 \mathrm{~min}$ at room temperature. 


\section{Statistical analysis}

Statistical differences between parameters assessed in sham and MCAO groups were determined by Student's $t$ test. Values of $p \leq 0.05$ were considered significant.

\section{Results}

\section{Stroke induction in male C57BL/6 mice}

We quantified changes in cell numbers in the spleen, and mRNA and protein levels for cytokines, chemokines, and chemokine receptors (CCR) in brain and spleen $96 \mathrm{~h}$ after reversible $\mathrm{MCAO}$ or sham treatment in male C57BL/6 mice. Infarction was present in all animals, and damage was consistent with previous work in this model. Infarct volume was assessed at 4 days and expressed as a percentage of the corresponding contralateral structure: cortex $52 \pm 4 \%$ and caudate putamen $77 \pm 9 \%$. Total infarct was $53 \pm 4 \%$ of contralateral hemisphere.

\section{MCAO-induced changes in cytokines and chemokines in brain}

In a previous report, we found striking increases in many inflammatory cytokines, chemokines, and chemokine receptor levels in postischemic brain after 6 and $22 \mathrm{~h}$ (7). By $96 \mathrm{~h}$ after stroke, the pattern of expression of these factors changed to a less inflammatory profile in the MCAOaffected right hemisphere. As is shown in Fig. 1, there was generally very low levels of expression of most the inflammatory cytokines and chemokines (IFN- $\gamma$, TNF- $\alpha$, IL-6, IL-17, IL-23, RANTES, IP-10, and CCR8), with the exception of IL-1 $\beta$, IL-2, and MIP-2, and an increase in expression of anti-inflammatory cytokines, IL-10 and TGF- $\beta 1$. Expression of chemokine receptors in the MCAO-affected right hemisphere was similar to or reduced in MCAO vs sham-treated mice (Fig. 1). Of interest, there was an increased expression of several inflammatory factors, including IFN- $\gamma$, IL-2, MIP-2, and CCR5 in the contralateral left hemisphere of MCAO vs sham-treated mice (Fig. 1).

\section{MCAO induces atrophy in the spleen and thymus}

In our previous study, we demonstrated that ischemia induced early cytokine changes in distant peripheral immune cell populations, including spleen, at the 6- and 22-h time points after MCAO. To determine whether stroke induced later immunosuppressive effects, we evaluated spleen and thymic morphology, and splenic histology and immune function $96 \mathrm{~h}$ after MCAO. As is shown in Fig. 2, gross morphology demonstrated an obvious reduction in the sizes of spleens and thymi from MCAO- vs sham-treated mice. This striking change in spleen size was reflected by a reduction of lymphoid tissue and marked reduction of hemopoietic elements in the red pulp throughout the spleen from MCAO mice compared with sham-operated mice (Fig. 3). The spleens of MCAO-treated mice also exhibited increased numbers of DNA-damaged cells (data not shown) and lack of germinal centers within the remnant lymphoid tissue (Fig. $3)$.

\section{Changes $96 \mathrm{~h}$ after stroke include rampant spleen cell death and decreased cytokine production, but an increase in $\mathrm{CD}^{+}{ }^{+}$FoxP3 ${ }^{+}$Treg cells and circulating $\mathrm{CD} 11 \mathrm{~b}^{+}$macrophages/ dendritic cells (DC)}

As is shown in Table I, there was a significant reduction in the total number of mononuclear cells per spleen as early as $6 \mathrm{~h}$ after performing either MCAO or sham procedures compared with naive untreated mice. By $22 \mathrm{~h}$ postocclusion, there was a further significant reduction of splenocytes in MCAO- vs sham-treated mice. By $96 \mathrm{~h}$ after MCAO, spleen cell numbers were drastically decreased in stroke mice, whereas spleen cell numbers in sham-treated mice returned to near normal levels. It is noteworthy that stroke also induced a similar degree of 
atrophy and cell loss in the thymus at $96 \mathrm{~h}$, from 78 million cells in sham-treated mice to only 1.7 million cells in MCAO mice.

We further evaluated splenocyte responses to T cell mitogens, Con A and anti-CD3 mAb, and to LPS in naive, sham, and stroke mice. As is shown in Fig. 4, splenocyte proliferation responses $22 \mathrm{~h}$ after MCAO were moderately but significantly reduced upon stimulation with two different concentrations of Con A, but not with LPS (data not shown). By $96 \mathrm{~h}$ after stroke, total spleen size and cell numbers and T cell responses to both Con A and anti-CD3 mAb were reduced $>90 \%$ (Table I and Fig. 4). Moreover, the 96-h MCAO spleens had strongly reduced secretion and message levels for inflammatory cytokines, TNF- $\alpha$, IFN- $\gamma$, and IL-6 (Figs. 5 and $6)$.

To determine whether the reduction in splenocyte number and $\mathrm{T}$ cell responsiveness was due to cell death, splenocytes were evaluated for expression of annexin V and TUNEL, two markers of cell commitment to apoptosis. This evaluation of spleen cells $22 \mathrm{~h}$ after occlusion showed an increase in annexin V staining in MCAO vs sham B cells $(12.5 \pm 0.7 \%$ vs $8.4 \pm 0.7 \%, p=$ $0.028)$ and $\mathrm{CD}^{+} \mathrm{T}$ cells $(4.7 \pm 0.2 \%$ vs $1.6 \pm 0.2 \%, p<0.01)$. Moreover, there was a moderate increase in $\mathrm{TUNEL}^{+}$splenocytes detected in situ (Fig. 7). In the 96-h spleens from MCAO mice, the reduced cellularity and cytokine responses noted above were reflected by a striking increase in TUNEL ${ }^{+}$cells (Fig. 7), and in propidium iodide-positive $\left(\mathrm{PI}^{+}\right)($dying) splenocytes (Fig. 8).

These data reveal that the striking reduction in splenocyte number and hyporesponsiveness to $\mathrm{T}$ cell mitogens is likely a direct consequence of splenic cell death that occurs by $96 \mathrm{~h}$ after focal cerebral ischemia. An alternative explanation involves a shift in the distribution of splenocyte subtypes. Indeed, as is shown in Table II, there was a significant decrease in the percentage of B cells (consistent with the loss of germinal centers shown in Fig. $3 B$ above) that constitute the majority of splenocytes, but a significant increase in the percentage of $\mathrm{CD}^{+}$, $\mathrm{CD}^{+}$, and $\mathrm{CD} 8^{+} \mathrm{T}$ cells at the $96-\mathrm{h}$ time point. However, there was no change in the percentage of $\mathrm{CD} 11 \mathrm{~b}^{+}$macrophages or $\mathrm{CD} 11 \mathrm{c}^{+} \mathrm{DCs}$ in spleens from MCAO mice $96 \mathrm{~h}$ after stroke. Similar to spleen, there was also a 2-fold decrease in white cell counts per milliliter in blood. This was reflected largely by a significant decrease in the percentage of B cells (the dominant mononuclear cell type) and $\mathrm{CD}^{+} \mathrm{T}$ cells. However, in MCAO mice there was a striking increase in $\mathrm{CD}_{1} \mathrm{~b}^{+}$macrophages (Table II) that were found to be viable (annexin $\mathrm{V}$ negative, Fig. 9) and VLA-4 negative (Fig. 10). This suggests that by $96 \mathrm{~h}$, the VLA-4-positive cells had likely migrated to the brain or other tissues.

Despite the $90 \%$ loss of splenocytes at the $96-\mathrm{h}$ time point after cerebral vascular occlusion, MCAO-treated mice had an increase in FoxP3 message (Fig. 6) and a 3-fold increase in $\mathrm{CD}^{+} \mathrm{FoxP}^{+}$Treg cells compared with naive or sham-treated mice (Fig. 11). Induction of Treg cells following stroke clearly occurred after the initial surge in inflammatory cytokines, because there was no increase in Treg cells at the 22-h time point (data not shown). These results strongly indicate a general loss of B cells in spleen, with a relative enrichment of $\mathrm{T}$ cells, including $\mathrm{CD}^{+}$Treg cells, and appearance of $\mathrm{CD} 11 \mathrm{~b}^{+}$macrophages/monocytes that remain in the blood stream. Loss of responsiveness to anti-CD3 and Con A by splenic T cells can thus be at least partially explained by a striking increase in FoxP3 expression and in the percentage of $\mathrm{CD} 4^{+}$Treg cells.

\section{Discussion}

Clinical stroke and experimental cerebral ischemia induce local inflammatory processes that undoubtedly contribute to total cerebral injury. Within hours, transcription factors are upregulated locally in brain tissue e.g., NF- $\kappa$ B (18) that up-regulates proinflammatory genes, 
including the cytokines TNF- $\alpha(19)$, IL-1 $\beta(20,21)$, IL-6 (22), and IL-1 receptor antagonist (23), and chemokines such as IL-8 (20), IP-10 (24), and MCP-1 $(25,26)$. These factors promote expression of adhesion molecules by vascular endothelial cells that allow infiltration into the brain of blood neutrophils, monocytes, macrophages, and $\mathrm{T}$ cells that promote further brain injury (27).

In our previous report, we found striking increases in inflammatory cytokines and chemokines in the MCAO-affected right hemisphere at the 6- and 22-h time points postocclusion. Interestingly, this pattern appeared to change by $96 \mathrm{~h}$ to a much less inflammatory profile, with a low but significant increase in only IL-2 and MIP-2 in the affected right hemisphere, and IL-2, MIP-2, IFN- $\gamma$, and CCR5 in the contralateral hemisphere. These findings suggest a reduction in the inflammatory phase in the damaged brain area by $96 \mathrm{~h}$ postocclusion.

The effects of cerebral damage from stroke are not limited to brain tissue. Stroke also induces profound effects on the peripheral immune system, including an early activation phase lasting 1-2 days, followed by severe systemic immunosuppression. In our previous report (7), we characterized a largely inflammatory cytokine profile in spleen and blood that was apparent as early as $6 \mathrm{~h}$ after cerebral vascular occlusion and was still evident $22 \mathrm{~h}$ after stroke. In this report, we further characterized the drastic effects of stroke on the gross morphology and cell numbers in spleen and thymus, and on splenocyte function and cellular distribution by $96 \mathrm{~h}$ after stroke.

Both spleen and thymus from mice with stroke were obviously atrophied. Moreover, we observed a profound $90 \%$ reduction in spleen cell numbers, and verified a similar loss of cellularity in the thymus of MCAO mice. Functionally, the stroke process reduced splenic T cell proliferation and secretion of inflammatory cytokines in response to mitogen stimulation. These changes were accompanied by an increase in splenocytes that were committed to the apoptotic pathway (i.e., that were TUNEL positive, annexin $\mathrm{V}^{+}$, or $\mathrm{PI}^{+}$) or that appeared to be overtly apoptotic in histopathologic sections. However, cell death represented only one of the processes that contributed to splenic atrophy and loss of $\mathrm{T}$ cell responsiveness to mitogen stimulation. The major new findings in our study include the relatively selective reduction in $\mathrm{B}$ cells in spleen and blood, the pronounced increase in splenic $\mathrm{CD} 4^{+}$Treg cells, and the increased presence of circulating monocytes/macrophages that all occur by $96 \mathrm{~h}$ after stroke induction. Reduced cellularity in spleen and/or thymus was observed in mice and rats after stroke in two previous reports $(5,6)$, and our data emphasizes this important feature induced by stroke-induced brain damage.

In mice, B cells constitute $\sim 60 \%$ of splenic and blood mononuclear cells. By $96 \mathrm{~h}$ after stroke, the percentage of B cells was reduced by about half to $\sim 30 \%$ of the remaining splenic and blood mononuclear cells. When translated to total cells, this represents a reduction from 45 million to only 2.5 million B cells per spleen, and a $>80 \%$ reduction in the number of B cells per milliliter of blood. This degree of B cell loss just 4 days after stroke would undoubtedly compromise the ability of the humoral immune system to provide protection against invading microorganisms. Should a comparable level of B cell depletion occur in human stroke patients, this damaging effect of stroke by itself could largely account for the high rates of lethal infections.

A second important mechanism of immunosuppression induced by stroke at $96 \mathrm{~h}$ appears to be the induction of $\mathrm{CD} 4{ }^{+} \mathrm{CD} 25^{+}$Treg cells that are considered to be "master regulators" of the immune system. Initial descriptions indicated that Treg cells expressed very high levels of the IL-2R, CD25, and consequently these cells are often referred to as $\mathrm{CD} 4{ }^{+} \mathrm{CD} 25^{+}$or $\mathrm{CD} 4{ }^{+} \mathrm{CD} 25^{\text {bright }}$. In normal mice, Treg cells limit inflammation and inhibit autoimmune diseases $(12,13,28,29)$. The forkhead/winged helix transcription factor gene, FoxP 3 , is strongly 
linked to the regulatory function of $\mathrm{CD} 4{ }^{+} \mathrm{CD} 25^{+}$Treg cells (30-32), and has become a useful intracellular marker for their identification. Although a normal complement of Treg cells specific for self-tissue determinants may maintain self-tolerance (33), it is now appreciated that an over-abundance of Treg cells may impede immunosurveillance against autologous tumor cells (14) and may suppress the ability of $\mathrm{CD} 4^{+} \mathrm{CD} 25^{-}$effector $\mathrm{T}$ cells to eliminate parasites (11). Taken together, these findings document the importance of the $\mathrm{CD} 4^{+} \mathrm{CD} 25^{+}$ Treg cell subpopulation in regulating autoreactive as well as protective $\mathrm{T}$ effector cells in vivo.

The underlying process that results in widespread immunosuppression and concurrent systemic infections after stroke induction (5) is not well understood. However, it is conceivable that sympathetic signaling to the spleen and thymus might stimulate an overabundance of Treg cells that could inhibit protective immune cells, including $\mathrm{CD} 4^{+}$and $\mathrm{CD}^{+} \mathrm{T}$ cells, B cells, and NK cells. This idea gains some support from a recent study showing that naturally occurring Treg cells can suppress the protective function of myelin-reactive $T$ cells against neuronal injury (34). Based on the observed increases in the percentage of $\mathrm{CD}^{+}{ }^{+} \mathrm{CD} 4^{+} \mathrm{FoxP}^{+}$Treg cells in the spleen in the face of the drastic reduction in splenocyte numbers induced by stroke, one might conclude that the Treg cell population is relatively resistant to apoptosis or other mechanisms that act to reduce viable spleen cell numbers.

The pronounced increase in the percentage of $\mathrm{CD} 11 \mathrm{~b}^{+}$macrophages/monocytes in blood represents the third novel finding in our study. These circulating cells are clearly viable (annexin V negative), and they also do not express the VLA-4 marker that would otherwise permit these cells to infiltrate into the tissues, including the stroke-damaged brain. Although we have not yet established a role for the $\mathrm{CD} 11 \mathrm{~b}^{+}$macrophage/monocyte population in the observed immunosuppression, our studies indicate that certain subtypes of macrophages and DCs (that are also CD $11 b^{+}$) can potentiate activation of Treg cells and reduce the activation of $\mathrm{T}$ effector cells (35). The functional properties of the stroke-induced $\mathrm{CD} 11 \mathrm{~b}^{+}$cells related to immunosuppression will be the subject of a separate report.

In summary, our study provides for the first time new evidence to support the contention that damage to the brain caused by cerebral ischemia provides a powerful negative signal to the peripheral immune system that ultimately induces a drastic state of immunosuppression and increased risk of mortality.

\section{Acknowledgements}

We thank Eva Niehaus for assistance in preparing and submitting the manuscript.

\section{References}

1. Allan SM, Rothwell NJ. Inflammation in central nervous system injury. Phil Trans R Soc Lond 2003;358:1669-1677. [PubMed: 14561325]

2. del Zoppo GJ, Becker KJ, Hallenbeck JM. Inflammation after stroke: is it harmful? Arch Neurol 2001;58:669- 672. [PubMed: 11296002]

3. Emsley HCA, Smith CJ, Gavin CM, Georgiou RF, Vail A, Barberan EM, Hallenbeck JM, del Zoppo GJ, Rothwell NJ, Tyrrell PJ, Hopkins SJ. An early and sustained peripheral inflammatory response in acute ischaemic stroke: relationships with infection and atherosclerosis. J Neuroimmunol 2003;139:93-101. [PubMed: 12799026]

4. Smith CJ, Emsley HCA, Gavin CM, Georgiou RF, Vail A, Barberan EM, del Zoppo GJ, Hallenbeck JM, Rothwell NJ, Hopkins SJ, Tyrrell PJ. Peak plasma interleukin-6 and other peripheral markers of inflammation in the first week of ischaemic stroke correlate with brain infarct volume, stroke severity and long-term outcome. BMC Neurol 2004;4:2-7. [PubMed: 14725719]

5. Prass K, Meisel C, Hoflich C, Braun J, Halle E, Wolf T, Ruscher K, Victorov IV, Priller J, Dirnagl U, et al. Stroke-induced immunodeficiency promotes spontaneous bacterial infections and is mediated 
by sympathetic activation reversal by poststroke T helper cell type 1-like immunostimulation. J Exp Med 2003;198:725-736. [PubMed: 12939340]

6. Gendron A, Teitelbaum J, Cossette C, Nuara S, Dumont M, Geadah D, du Souch P, Kouassi E. Temporal effects of left versus right middle cerebral artery occlusion on spleen lymphocyte subsets and mitogenic response in Wistar rats. Brain Res 2002;955:85-97. [PubMed: 12419524]

7. Offner H, Subramanian S, Parker SM, Afentoulis ME, Vandenbark AA, Hurn PD. Experimental stroke induces massive, rapid activation of the peripheral immune system. J Cereb Blood Flow Metab 2006;26:654- 665. [PubMed: 16121126]

8. Prass K, Ruscher K, Karsch M, Isaev N, Megow D, Priller J, Scharff A, Dirnagl U, Meisel A. Desferrioxamine induces delayed tolerance against cerebral ischemia in vivo and in vitro. $\mathrm{J}$ Cereb Blood Flow Metab 2002;22:520-525. [PubMed: 11973424]

9. Mergenthaler P, Dirnagl U, Meisel A. Pathophysiology of stroke: lessons from animal models. Metab Brain Dis 2004;19:151-167. [PubMed: 15554412]

10. Meyer S, Strittmatter M, Fischer C, Georg T, Schmitz B. Lateralization in autonomic dysfunction in ischemic stroke involving the insular cortex. Neuroreport 2004;15:357-361. [PubMed: 15076768]

11. Belkaid Y, Piccirillo CA, Mendez S, Shevach EM, Sachs DL. CD4 ${ }^{+} \mathrm{CD} 25^{+}$regulatory T cells control Leishmania major persistence and immunity. Nature 2002;420:502-507. [PubMed: 12466842]

12. Maloy KJ, Powrie F. Regulatory T cells in the control of immune pathology. Nat Immunol 2001;2:816- 822. [PubMed: 11526392]

13. Roncarolo MG, Levings MK. The role of different subsets of T regulatory cells in controlling autoimmunity. Curr Opin Immunol 2000;12:676- 683. [PubMed: 11102772]

14. Shimizu J, Yamazaki S, Sakaguchi S. Induction of tumor immunity by removing CD $25^{+} \mathrm{CD} 4^{+} \mathrm{T}$ cells: a common basis between tumor immunity and autoimmunity. J Immunol 1999;163:5211-5218. [PubMed: 10553041]

15. McCullough LD, Hurn PD. Estrogen and neuroprotection. Trends Endocrinol Metab 2003;14:228235. [PubMed: 12826329]

16. Sawada M, Alkayed NJ, Goto S, Crain BJ, Traystman RJ, Shaivitz A, Nelson RJ, Hurn PD. Estrogen receptor antagonist ICI182,780 exacerbates ischemic injury in female mouse. J Cereb Blood Flow Metab 2000;20:112-118. [PubMed: 10616799]

17. Subramanian S, Matejuk A, Zamora A, Vandenbark AA, Offner H. Oral feeding with ethinyl estradiol suppresses and treats experimental autoimmune encephalomyelitis in SJL mice and inhibits the recruitment of inflammatory cells into the central nervous system. J Immunol 2003;170:1548-1555. [PubMed: 12538720]

18. O'Neill LA, Kaltschmidt C. NF- $\kappa$ B: a crucial transcription factor for glial and neuronal cell function. Trends Neurosci 1997;20:252-258. [PubMed: 9185306]

19. Liu T, Clark RK, McDonnell PC, Young PR, White RF, Barone FC, Feuerstein GF. Tumour necrosis factor a expression in ischemic neurons. Stroke 1994;25:1481-1488. [PubMed: 8023366]

20. Liu T, McDonnell PC, White RF, Barone FC, Feuerstein GZ. Interleukin- $1 \beta$ mRNA expression in ischemic rat cortex. Stroke 1993;24:1746-1751. [PubMed: 8236352]

21. Wang XK, Yue TL, Barone FC, White R, Young PR, McDonnell PC, Feuerstein GZ. Concomitant cortical expression of TNF- $\alpha$ and IL- $1 \beta$ mRNA following transient focal ischemia. Mol Chem Neuropathol 1994;23:103-114. [PubMed: 7702701]

22. Wang XK, Yue TL, Young PR, Barone FC, Feuerstein GZ. Expression of interleukin-6, c-fos and zif268 mRNA in rat ischemic cortex. J Cereb Blood Flow Metab 1995;15:166-171. [PubMed: 7798334]

23. Wang XK, Barone FC, Aiyar NV, Feuerstein GF. Increased interleukin-1 receptor and interleukin-1 receptor antagonist gene expression after focal stroke. Stroke 1997;28:155-162. [PubMed: 8996505]

24. Wang XK, Ellison JA, Siren AL, Lysko PG, Yue TL, Barone FC, Shatzman A, Feuerstein GF. Prolonged expression of interferon inducible protein-10 in ischemic cortex after permanent occlusion of the middle cerebral artery in the rat. J Neurochem 1998;71:1194-1204. [PubMed: 9721745]

25. Kim JS, Gautam SC, Chopp M, Zaloga C, Jones ML, Ward PA, Welch KMA. Expression of monocyte chemoattractant protein-1 and macrophage inflammatory protein-1 after focal cerebral ischemia in the rat. J Neuroimmunol 1995;56:127-134. [PubMed: 7860708] 
26. Wang XK, Yue TL, Barone FC, Feuerstein GF. Monocyte chemoattractant protein-1 (MCP-1) mRNA expression in rat ischemic cortex. Stroke 1995;26:661- 666. [PubMed: 7709415]

27. Barone FC, Feuerstein GZ. Inflammatory mediators and stroke: new opportunities for novel therapeutics. J Cereb Blood Flow Metab 1999;19:819- 834. [PubMed: 10458589]

28. Mason D, Powrie F. Control of immune pathology by regulatory T cells. Curr Opin Immunol 1998;10:649- 655. [PubMed: 9914214]

29. Shevach EM. Regulatory T cells in autoimmunity. Annu Rev Immunol 2000;18:423-449. [PubMed: 10837065]

30. Fontenot JD, Gavin MA, Rudensky AY. Foxp3 programs the development and function of CD4 ${ }^{+} \mathrm{CD} 25^{+}$regulatory T cells. Nat Immunol 2003;4:330-336. [PubMed: 12612578]

31. Hori S, Nomura T, Sakaguchi S. Control of regulatory T cell development by the transcription factor. Foxp3 Science 2003;299:1057-1061.

32. Khattri R, Cox T, Yasayko S, Ramsdell F. An essential role for Scurfin in CD ${ }^{+} \mathrm{CD} 25^{+} \mathrm{T}$ regulatory cells. Nat Immunol 2003;4:337-342. [PubMed: 12612581]

33. Sakaguchi S, Sakaguchi N. Regulatory T cells in immunologic self-tolerance and autoimmune disease. Int Rev Immunol 2005;24:211-226. [PubMed: 16036375]

34. Kipnis J, Mizrahi T, Hauben E, Shaked I, Shevach E, Schwartz M. Neuroprotective autoimmunity: naturally occurring $\mathrm{CD} 4{ }^{+} \mathrm{CD} 25^{+}$regulatory $\mathrm{T}$ cells suppress the ability to withstand injury to the central nervous system. Proc Nat Acad Sci USA 2002;99:15620-15625. [PubMed: 12429857]

35. Polanczyk MJ, Hopke C, Vandenbark AA, Offner H. Estrogen-mediated immunosuppression involves reduced activation of effector T cells, potentiation of Treg cells and enhanced expression of negative co-stimulatory ligands. J Neurosci Res. 2006In press 


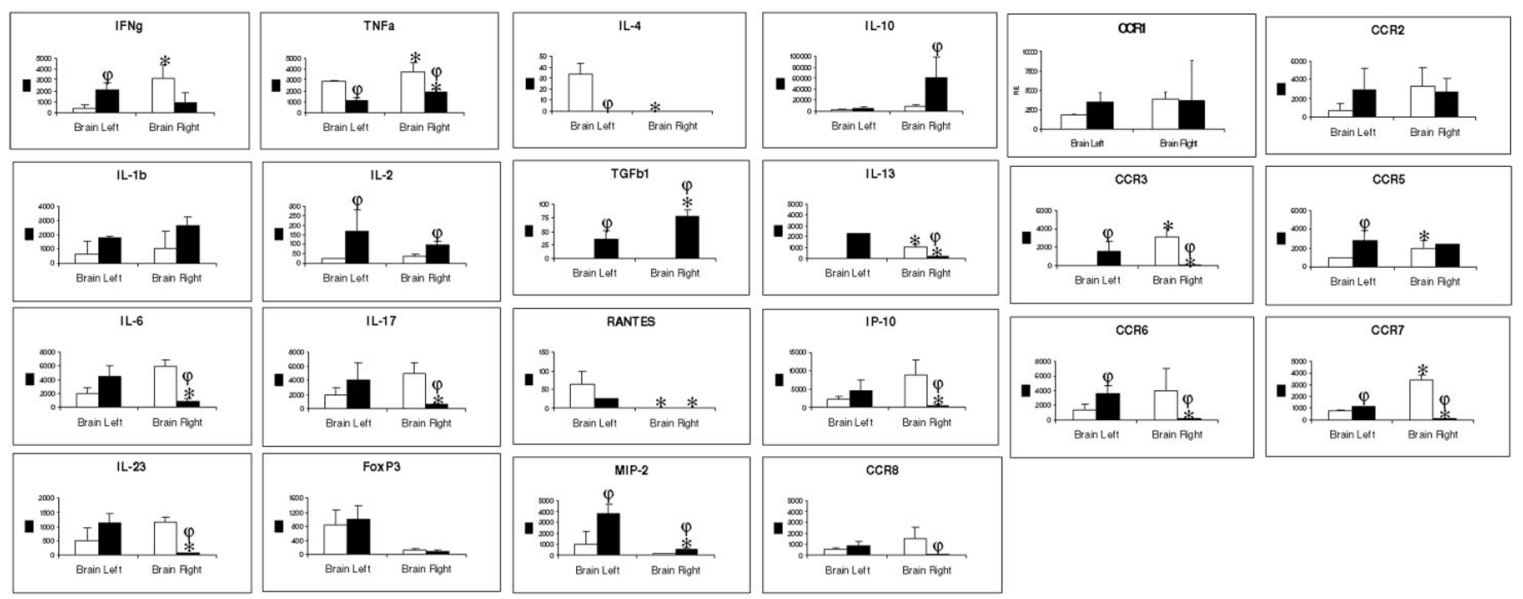

*=Significant difference between Brain Left and Brain Right $\varphi=$ Significant difference between SHAM and MCAO in same area of brain

FIGURE 1.

Effects of stroke on expression of cytokines and chemokines/receptors in CNS tissue. Brains were collected from sham and MCAO-treated mice $96 \mathrm{~h}$ after occlusion, and mRNA was prepared from ipsilateral (right) and contralateral (left) hemispheres of brain tissue for RTPCR analysis. Relative expression (RE) of message levels is presented for inflammatory cytokines, regulatory cytokines, chemokines, and chemokine receptors. $\phi$, A significant difference in expression in MCAO vs sham-treated mice. *, Significant change in expression in ipsilateral (right) vs contralateral (left) brain hemispheres. Data are presented as mean \pm SD. Each figure represents data from at least two separate experiments. Each experiment included two sham mice and three MCAO-treated mice. 


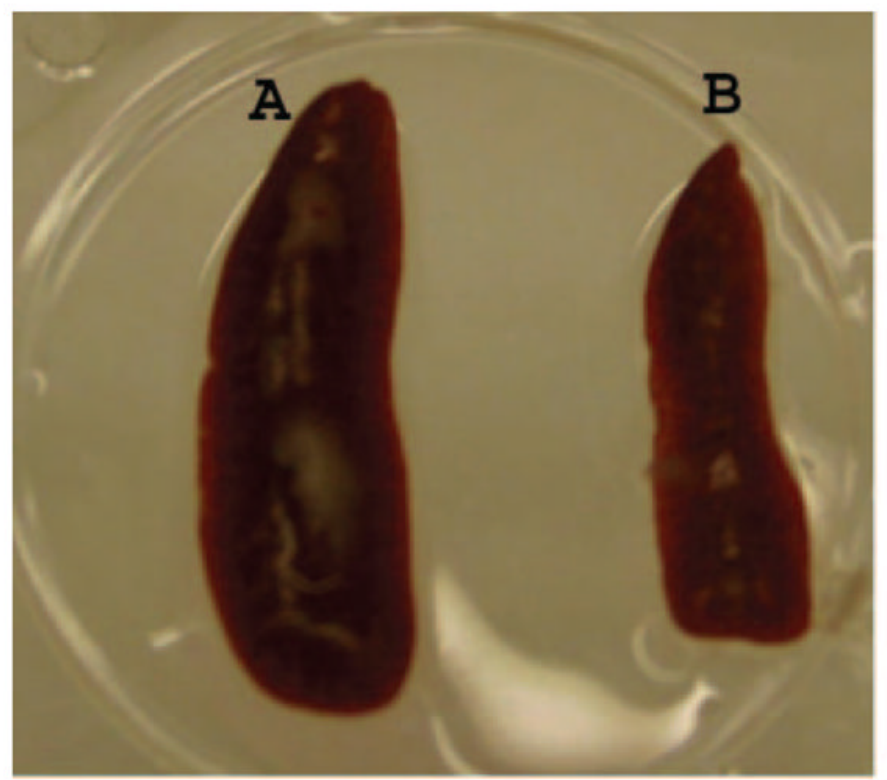

\section{SPLEEN}

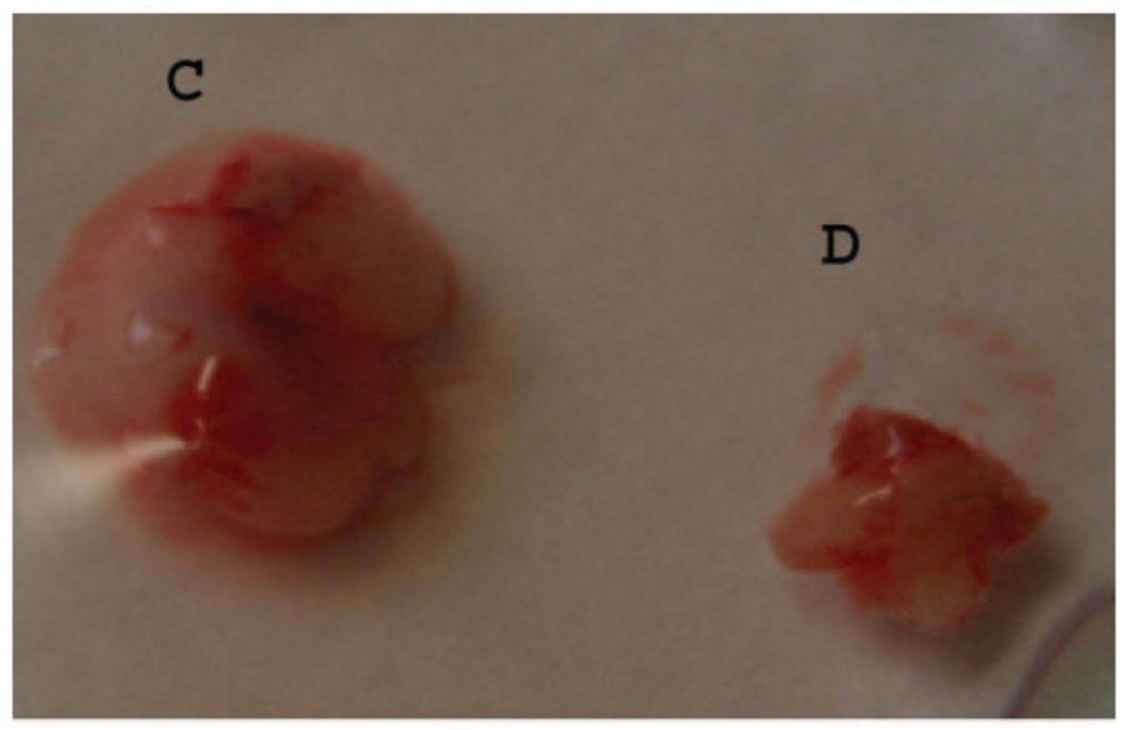

\section{THYMUS}

FIGURE 2.

Comparison of spleens and thymi obtained from sham-treated ( $A$ and $C$ ) and MCAO-treated $(B$ and $D)$ mice $96 \mathrm{~h}$ after occlusion. 
A

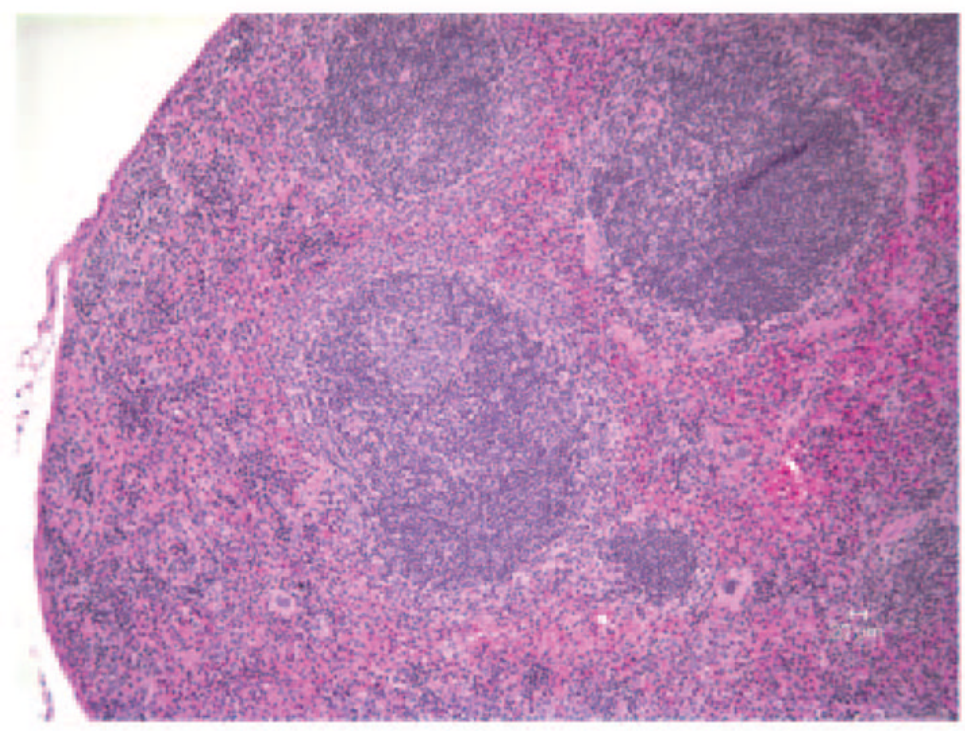

B

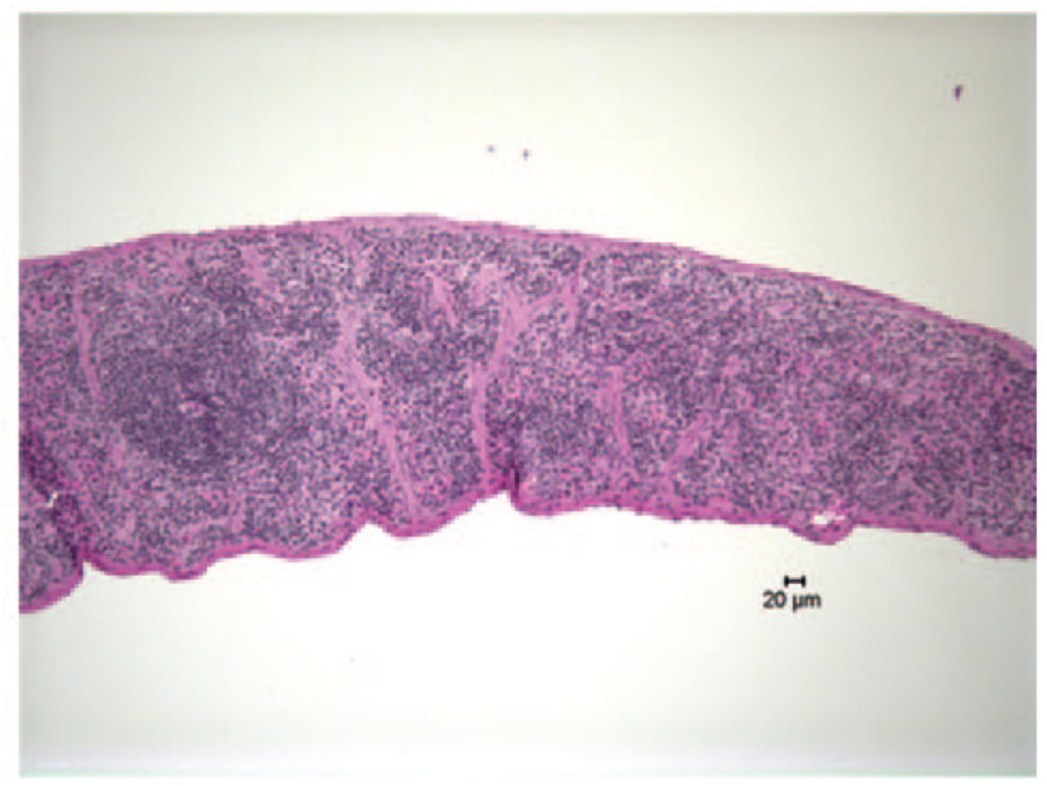

FIGURE 3.

Histopathology of spleens $96 \mathrm{~h}$ after $(A)$ sham treatment and (B) MCAO treatment of C57BL/ 6 mice. Representative section of MCAO spleen exhibits marked depletion of lymphoid tissue with lack of germinal centers. There is marked diffuse loss of normal extramedullary hemopoietic elements in the red pulp. Original magnification, $\times 100$. Representative section of sham spleen exhibits abundant lymphoid tissue and abundant extramedullary hemopoiesis. Central follicle contains a germinal center. Original magnification, $\times 100$. 

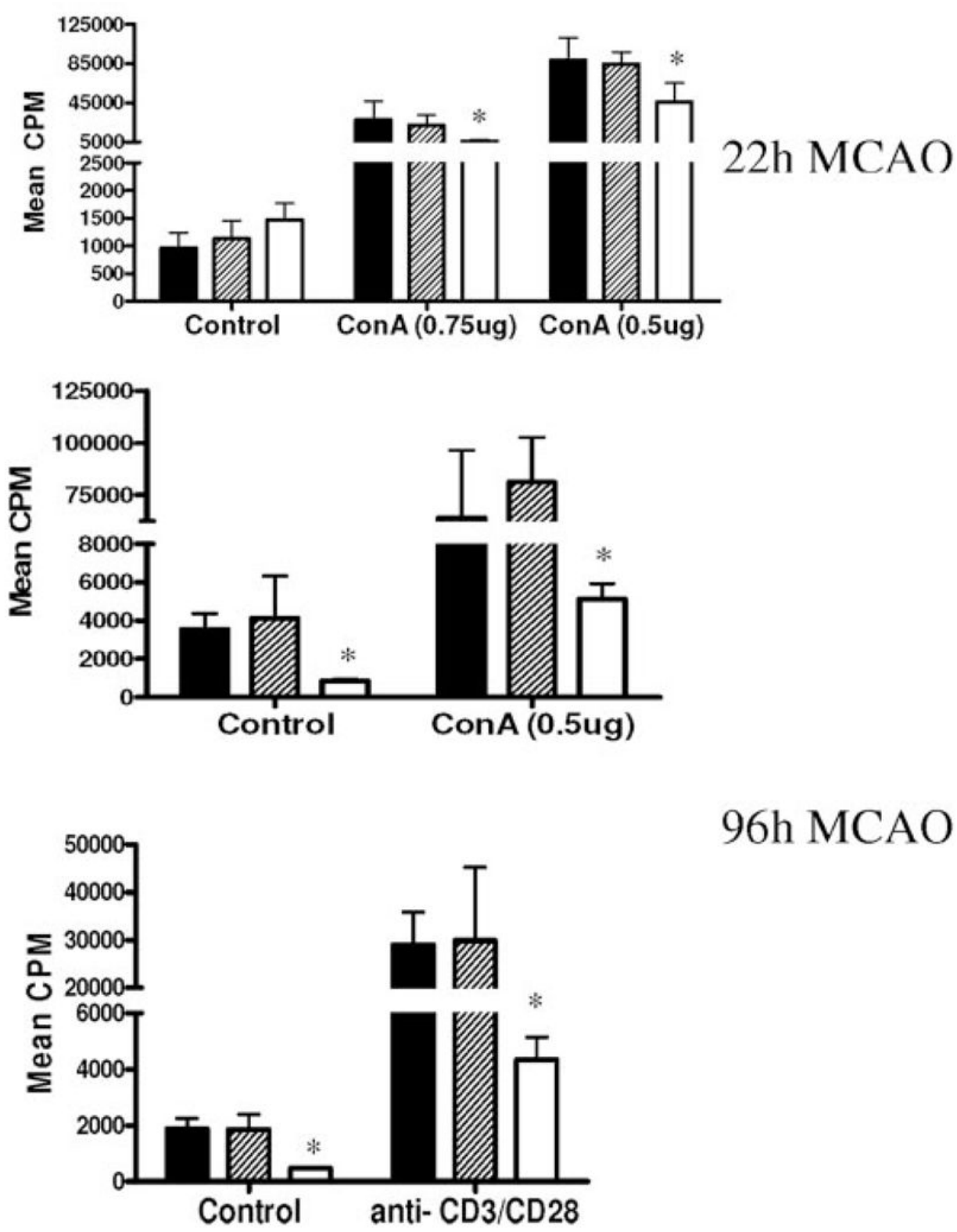

96h MCAO

FIGURE 4.

Proliferative response of splenocytes to mitogens 22 and $96 \mathrm{~h}$ after MCAO or sham treatment. Splenocytes were obtained from naive, sham-treated, and MCAO-treated mice 22 or $96 \mathrm{~h}$ after stroke and evaluated for proliferation responses 3 days after stimulation with 0.5 or $0.75 \mu \mathrm{g}$ of Con A, anti-CD3 mAb or medium. *, Significant reduction in response compared with naive or sham-treated mice. Data are presented as mean \pm SD. Each figure represents data from at least two separate experiments. Each experiment included two naive, two sham mice, and three MCAO-treated mice. 


\section{TNF- $\alpha$}
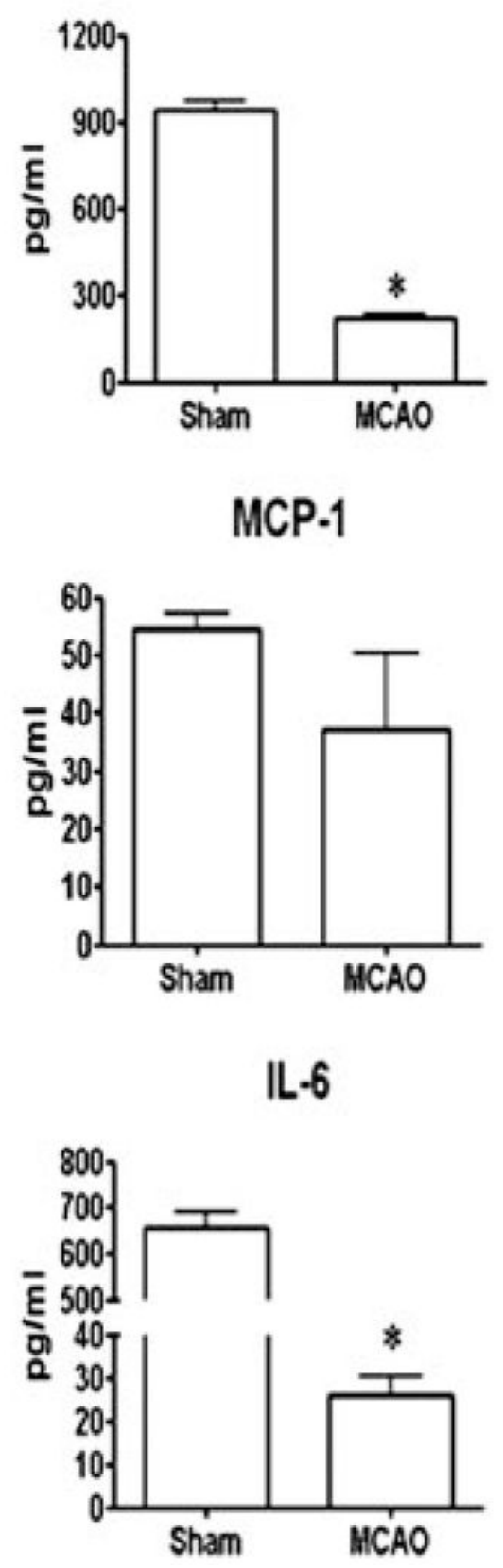

IFN-I

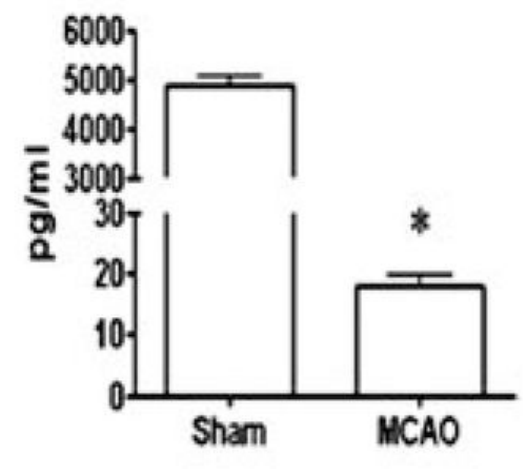

IL-10

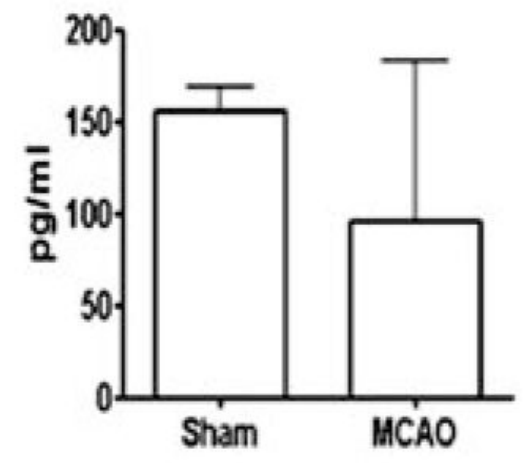

FIGURE 5.

Effects of stroke on cytokines secreted from stimulated splenocytes. Spleens were collected $96 \mathrm{~h}$ after vascular occlusion and immune cells were stimulated for $24 \mathrm{~h}$ with plate-bound antiCD3/CD28 Abs. Supernatants were evaluated for levels of secreted factors, including TNF$\alpha$, IFN- $\gamma$, IL-6, MCP-1, and IL-10. *, A significant difference in expression in stroke mice vs sham-treated mice. Data are presented as mean \pm SD. Each figure represents data from at least two separate experiments. Each experiment included two sham mice and three MCAO-treated mice. 

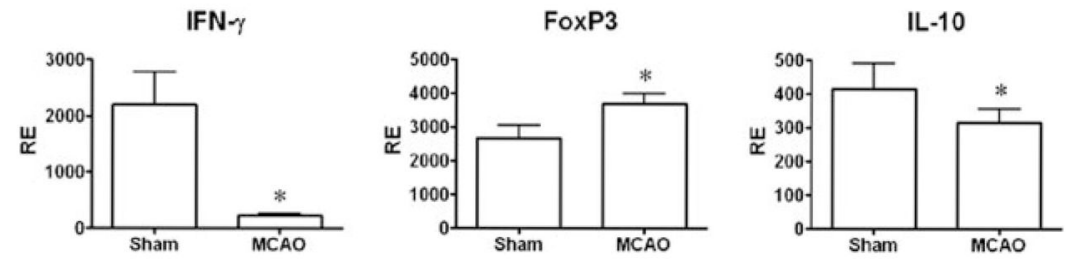

FIGURE 6.

Effect of stroke on expression of IFN- $\gamma$, FoxP3 and IL-10 in spleen tissue. Spleens were collected from Sham and MCAO treated mice $96 \mathrm{~h}$ after occlusion, and mRNA evaluated by RT-PCR for gene expression. *, A significant difference in expression in stroke mice vs shamtreated mice. Data are presented as mean $\pm \mathrm{SD}$. Each figure represents data from at least two separate experiments. Each experiment included two sham mice and three MCAO-treated mice. 

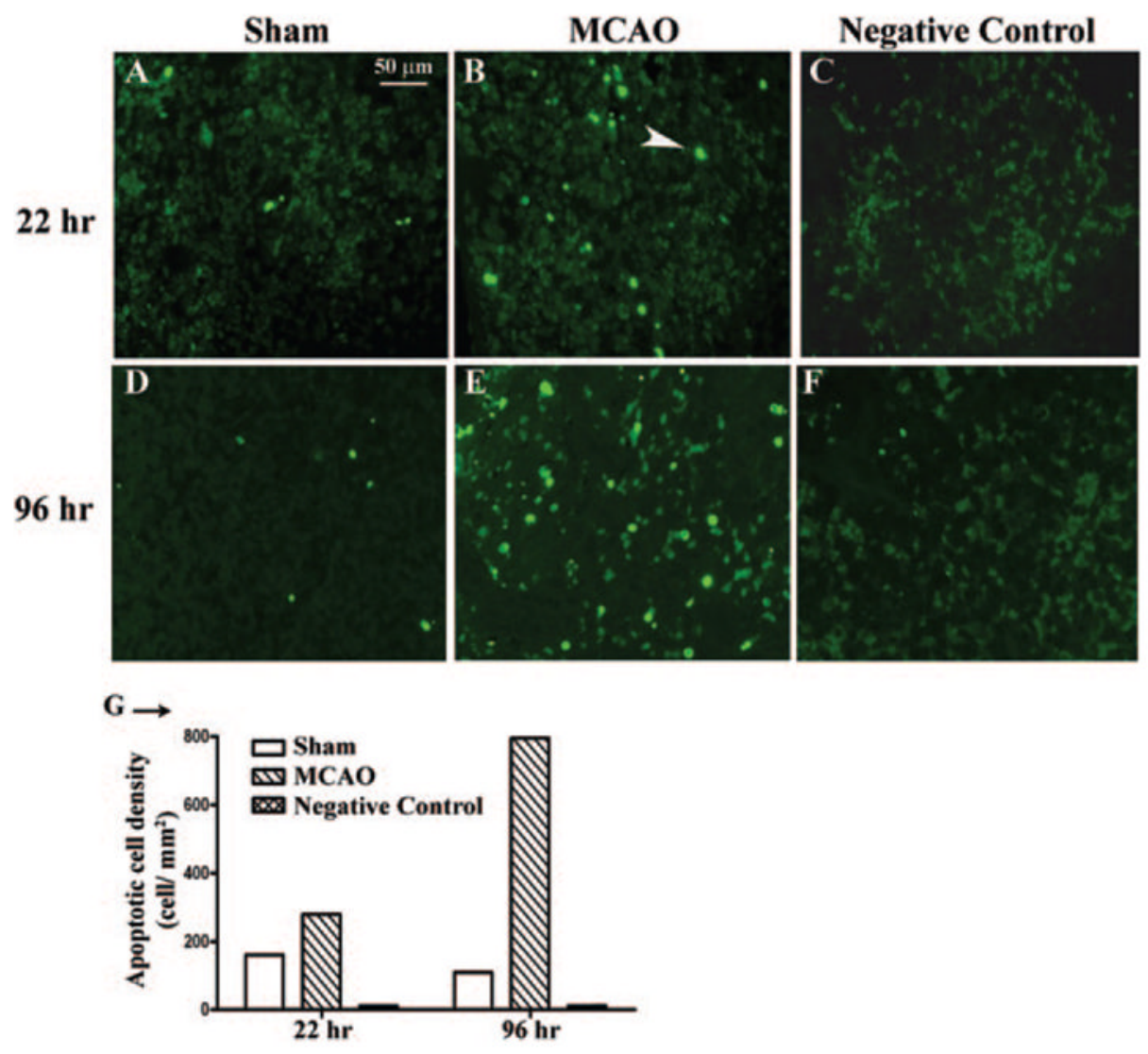

FIGURE 7.

In situ TdT-mediated dUTP nick end labeling (TUNEL) assay showed more apoptotic cells in MCAO than in sham mouse at 22 and $96 \mathrm{~h}$. ( $A, B, D$, and $E$ ): Fluorescence microscopic detection of apoptotic cells in mouse splenic tissues from sham $(A$ and $D)$ or MCAO ( $B$ and $E)$ mice, or in a section that was not treated with TdT enzyme ( $C$ and $F)$ negative control). $G$, Quantification of the TUNEL-positive cell density in different splenic sections. Splenic tissue sections were prepared and assayed with the In Situ Cell Death Detection kit, Fluorescein (Roche). One section from an MCAO mouse was treated with the same kit but not incubated with TdT enzyme in the labeling step, to serve as negative control. The section was viewed under a fluorescence microscope equipped with a digital camera. Apoptotic cells intensely stained (green) by the TUNEL treatment were counted and their densities were calculated by dividing the total number of apoptotic cells by the total area of the splenic section. A typical apoptotic cell is indicated by the white arrow. 

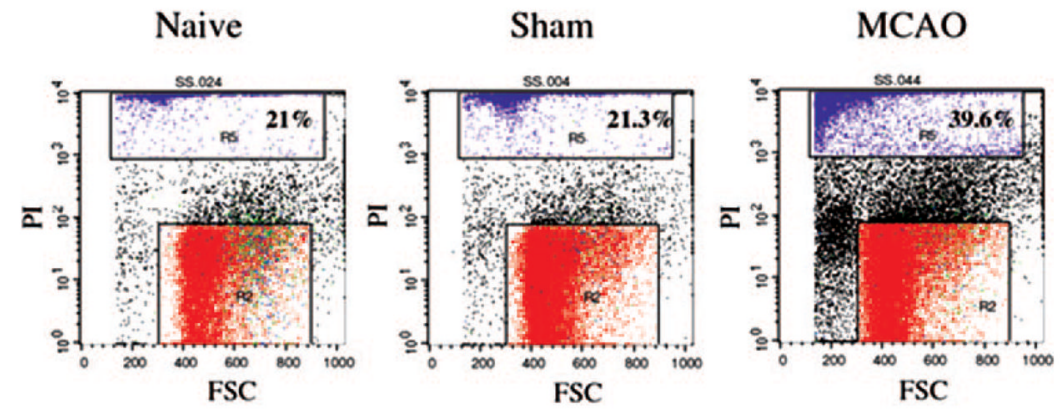

FIGURE 8.

Increase in dead spleen cells $96 \mathrm{~h}$ after MCAO. Splenocytes were obtained from naive, shamtreated, and MCAO-treated mice $96 \mathrm{~h}$ after stroke and evaluated for staining with PI, a vital dye that cannot be excluded by dead cells. Note increase in $\mathrm{PI}^{+}$cells in MCAO-treated mice (R5 gate). Data are presented as mean \pm SD. Each figure represents data from at least two separate experiments. Each experiment included two naive, two sham mice, and three MCAOtreated mice. 


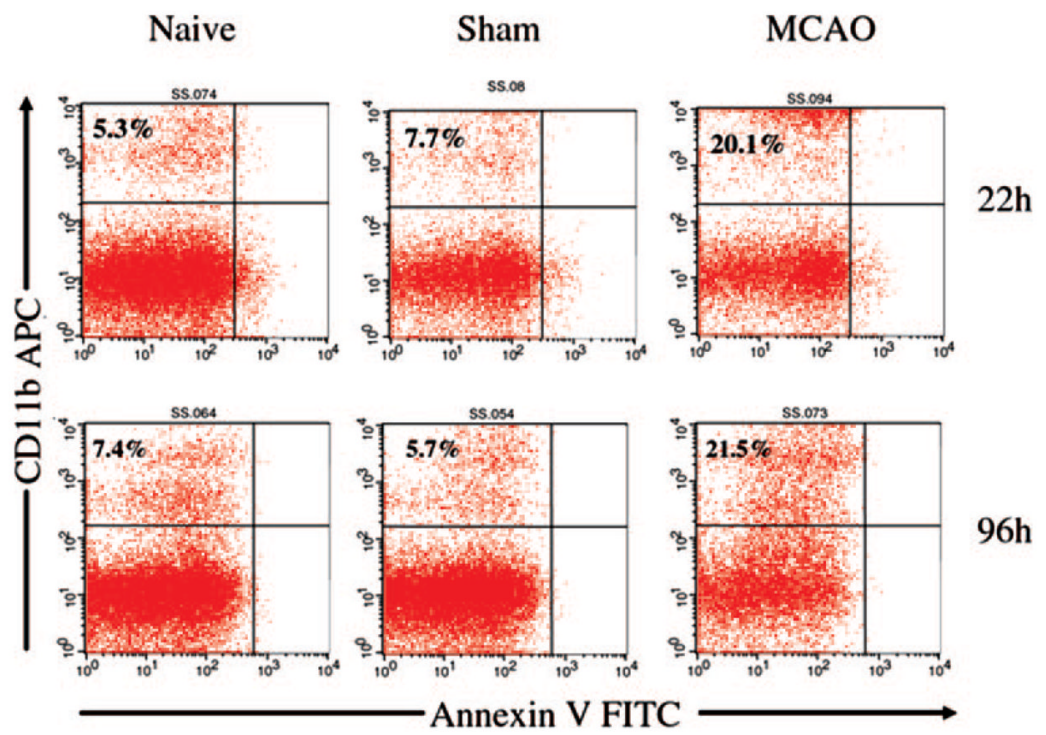

FIGURE 9.

Increase in viable macrophages in blood after MCAO. Blood mononuclear cells from naive, sham-treated, and MCAO-treated mice were evaluated 22 and $96 \mathrm{~h}$ after stroke induction for expression of $\mathrm{CD} 11 \mathrm{~b}$ (macrophages) and annexin $\mathrm{V}$ (apoptosis marker). Note increase in annexin V-negative CD11 $\mathrm{b}^{+}$cells (upper left quadrant) in MCAO-treated mice at both time points. Each figure represents data from at least two separate experiments. Each experiment included two naive, two sham mice, and three MCAO-treated mice. 

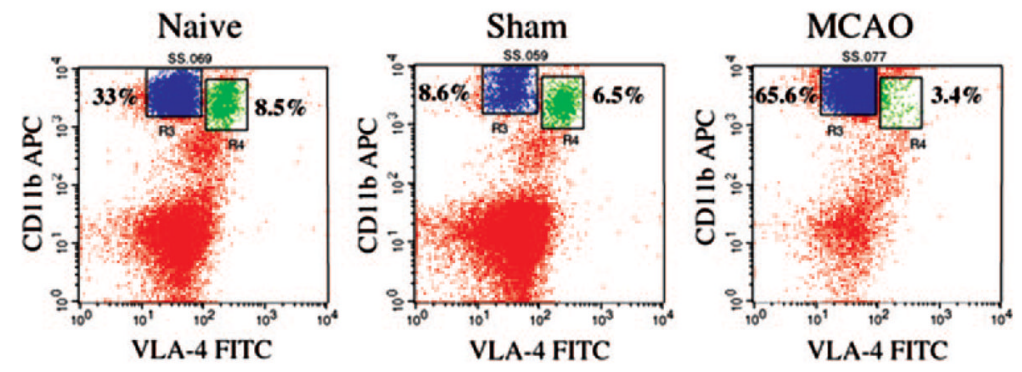

\section{FIGURE 10.}

Increase in VLA-4-negative macrophages in blood $96 \mathrm{~h}$ after MCAO. Blood mononuclear cells from naive, sham-treated, and MCAO-treated mice were evaluated $96 \mathrm{~h}$ after stroke induction for the expression of CD11b (macrophages) and VLA-4 (homing marker). Note striking increase in CD11 bright VLA-4-negative cells in MCAO-treated mice (R3 gate). Each figure represents data from at least two separate experiments. Each experiment included two naive, two sham mice, and three MCAO-treated mice. 

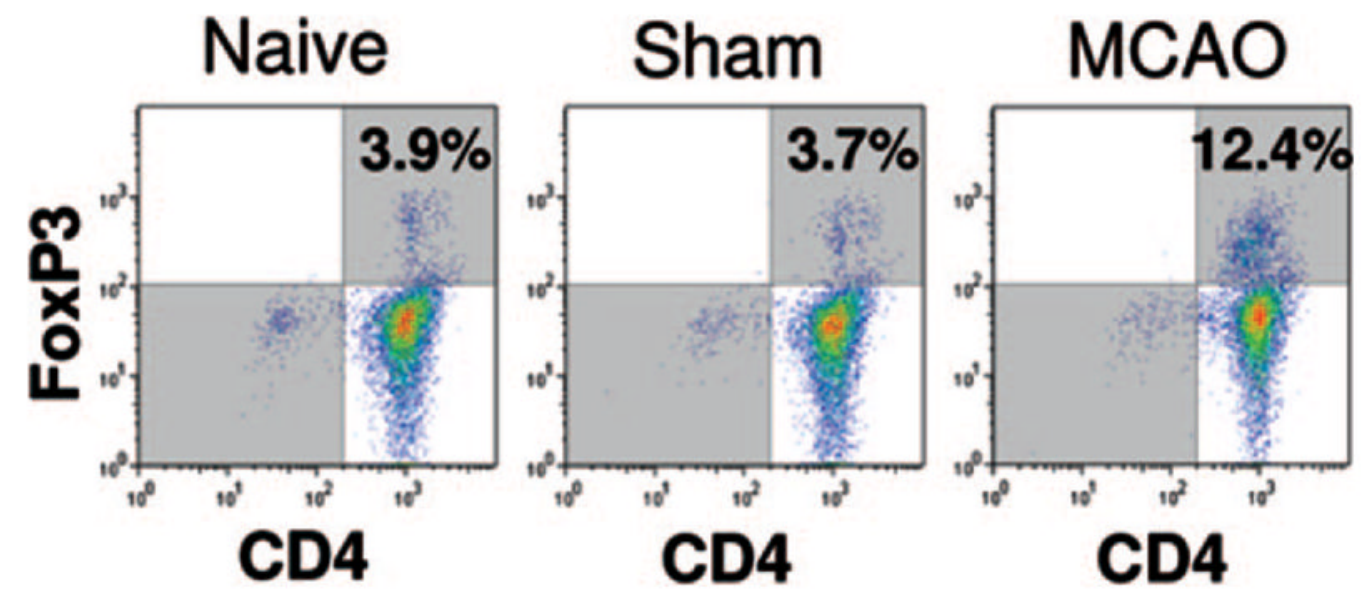

FIGURE 11.

Increase in $\mathrm{CD}^{+}$FoxP $3 \pm$ Treg cells in spleen $96 \mathrm{~h}$ after MCAO. Splenocytes were obtained from naive, sham-treated, and MCAO-treated mice $96 \mathrm{~h}$ after stroke and evaluated for staining with Abs to CD4 and FoxP3, a marker for Treg cells. Note increase in $\mathrm{CD}^{+} \mathrm{FoxP}^{+} \mathrm{T}$ cells in MCAO-treated mice (upper right quadrant). Each figure represents data from at least two separate experiments. Each experiment included two naive, two sham mice, and three MCAOtreated mice. 
Table I

Spleen cell yield $\left(\times 10^{6}\right)$ from sham and MCAO B6 male mice

\begin{tabular}{|c|c|c|}
\hline Time/Status & Sham & MCAO \\
\hline $\begin{array}{l}6 \mathrm{~h} \text { intact } \\
22 \mathrm{~h} \text { intact } \\
96 \mathrm{~h} \text { intact }\end{array}$ & $\begin{array}{c}50 \pm 14(4)^{a} \\
35 \pm 5(15)^{a} \\
80 \pm 7(7) \\
\text { Naive mice: } 91 \pm 8(4)\end{array}$ & $\begin{array}{c}46 \pm 4(3)^{a} \\
16 \pm 3(16)^{a, b} \\
8.8 \pm 7.6(11)^{a, b}\end{array}$ \\
\hline
\end{tabular}

${ }^{a}$ Value of $p<0.001$ vs naive mice; number of mice in parentheses.

${ }^{b}$ Value of $p<0.002$ vs sham-treated mice. 
Table II

Percentage of different cell types in spleen and blood of B6 mice after 4-day $\mathrm{MCAO}^{a}$

\begin{tabular}{lcc}
\hline Cell Type & Sham & MCAO \\
\hline Spleen & & $55.2 \pm 11.7^{b}$ \\
CD3 & $31.5 \pm 3.3$ & $33.0 \pm 8.1^{c}$ \\
CD4 & $19.9 \pm 2.8$ & $21.5 \pm 7.5^{c}$ \\
CD8 & $12.4 \pm 1.8$ & $6.9 \pm 4.9^{c}$ \\
CD11b & $5.2 \pm 1.9$ & $28.4 \pm 15.4^{c}$ \\
CD19 & $56.3 \pm 9.6$ & $1.3 \pm 1.0$ \\
CD11c & $3.0 \pm 1.7$ & $10.1 \pm 4.8^{c}$ \\
Blood & $18.3 \pm 0.06$ & $5.4 \pm 2.0$ \\
CD3 & $8.1 \pm 4.2$ & $3.6 \pm 2.9$ \\
CD4 & $7.9 \pm 0.4$ & $23.9 \pm 3.4^{c}$ \\
CD8 & $5.9 \pm 0.3$ & $34.1 \pm 20.6$ \\
CD11b & $63.7 \pm 18.8$ & $1.2 \pm 0.3$ \\
CD19 & $5.2 \pm 3.5$ & \\
CD11c & & \\
\hline
\end{tabular}

${ }^{a}$ Data are presented as mean \pm SD.

${ }^{b}$ Value of $p \leq 0.005$.

${ }^{c}$ Value of $p \leq 0.05$. 